\title{
Cultural Model in Chinese-to-English Translation: A Case Study of Guizhou's Local Culture*
}

\author{
XIAO Tang-jin, XIAO Zhi-peng \\ Guizhou Minzu University, Guiyang, Guizhou Province 550025, China
}

\begin{abstract}
Culture is an important component in translation. This paper reviews cultural translation researches and practices, proposes a cultural model for Chinese-to-English translation composed of inputs, filters and outputs which could be realized by a number of methods and techniques in the translating process, and finally applies the model to Chinese-to-English translation of Guizhou's local culture. It is argued that the cultural model is expected to draw international target text readers close to Chinese culture.
\end{abstract}

Keywords: cultural model, input, filter, output, translation

\section{Foreword}

Translation is a process of cultural communication and language learning. Traditionally it is defined as a conversion from the source language to the target language. In early stages translation theories laid much emphasis on faithfulness, expressiveness and elegance. Since the mid-20th century (particularly the 1990s) attention has been paid to culture in the translating processes and products, drawing inspirations from general linguistics, cognitive science, functional linguistics and cross-cultural communication. This paper is to review the relevant research, propose a cultural model for translation, and conduct a case study of Guizhou's local culture in Chinese-to-English translation. The present study is qualitative.

\section{Literature Review}

Basically cultural translation theories emphasize a relationship of correspondence and interaction between different levels. Bell (1991) proposes the term “discourse parameters” including participants, purpose and setting, matching separately tenor, mode and field in Halliday's Systemic Functional Grammar (p. 9). Tenor is participant relationship, mode is the expression form (oral, written, or combined), and field is the area concerning the events or activities. In linguistic forms tenor is realized by syntax, mode by syntax and lexis, and field by syntax and lexis. Bell's theory indicates that the interaction between the translator and the readers (mainly the target text

\footnotetext{
* Acknowledgements: This paper is funded by Guizhou Province's 2014 Comprehensive Academic Disciplinary Reform for the English Major, and it is also funded by Guizhou Province's 2015 Excellent Talent Cultivation Project "Colorful Guizhou Excellent English Communication Talent Cultivation”.

XIAO Tang-jin, Ph. D. in Linguistics, Professor of English, Dean of School of Foreign Languages, Guizhou Minzu University; research areas/interest: systemic functional grammar and text analysis.

XIAO Zhi-peng, master degree candidate of folklore (Batch 2016-2019), School of Ethnology and Sociology, Guizhou Minzu University; research areas/interest: folklore, ethnic tourism.
} 
readers) plays a crucial role in setting the tone, style and diction. For instance, a legal contract differs much from a letter of thanks in diction and syntactic structure, as the fields, tenors and modes concerned are profoundly discrepant. In the corresponding translating process the translator has to bear in mind the expectations of the target text readers. The translating process is thus a cultural one. Baker (1992) assumes that equivalence is the core of translating, covering four aspects, namely the word level, the level above word, the text level, and the pragmatic level (pp. 11-260). Obviously Baker stresses two categories of culture-language and society as well as their interplays in rendering an equivalent counterpart of the source text in the target language. Nida (2004) studies translation from cultural angles, reminding the translator of four aspects: (1) fully understanding the source text; (2) grasping the close relationship between language and culture; (3) paying attention to style and text; (4) exploring the relevance of translation from various perspectives. In Nida's view the connotations or associated meanings of words should never be ignored, for they are intricately relevant to style and text organization (pp. i-ii).

Cultural functions exert far-reaching impact on translation approaches and strategies. Nord (1997) generalizes the achievements of German functional translatologists and suggests the notion of "vertical unit" as opposed to the "horizontal unit", the former referring to a blending of linguistic and non-linguistic elements while the latter linguistic elements (pp. 49-52). Sager (1997) distinguishes “document” from "text” in translation, arguing that text is only a combination of content and form whereas document includes the intention of the source text writer (p. 34). The translator must ascertain if the text contains the source text writer's intention and consider whether to preserve it or not. Nord's view shows that translation is a highly cultural and contextual process, and Sager's idea reveals the translator's position—subjectivity and intersubjectivity. Subjectivity involves the translator's own standpoint while intersubjectivity marks the interaction between the translator and the source text writer as well as that between the translator and the target text readers. It can be found that cultural elements, including society, readers, writers and the translator, are highly valued in the translating processes and products.

Cultural translation is explicitly advocated by Katan (1999), who explores translation from such cultural angles as macro-level (including MacDonalization vs. globalization, logical and behavioral frames, values and beliefs, cognition, information load, affect, and high and low context) and micro-level (including formality, diction, and some specific techniques, for example, deletion, and overstatement and understatement). Cronin (2003) studies translation and globalization, arguing that globalization brings about new translation paradigms (diversity, mediation, de-materialization, networking, and fidelity vs. infidelity) and new politics (fluid modernity, translation and supra-national, cyborgs, and creativity). House (2016) distinguishes old thinking about culture from new thinking about culture in translation. The former is related to national characters, mentalities and stereotypes whereas the latter small cultures, communities of practice and superdiversity. Clearly in the translating process the translator in the new era has to consider such issues as translatability vs. untranslatability, functional-pragmatic views of context, translation quality assessment, and bilingual cognition.

Cultural approaches to translation were conducted by many scholars in the past two decades. Slingerland (2003) adopts the model of "preface + translation + explanation" in translating The Analects (a classic Confucian reader) from Chinese to English. In rendering the Confucian notion of 学 he uses the technique of "English + brackets including Pinyin and Chinese character”, i.e. 学—learning (xue 学). In so doing Slingerland manages to bring close both the source and target text readers, ignoring neither of them. Roberts (2001) undertakes the 
model of "introduction + content translation + notes" in rendering Dao De Jing (The Book of the Way, a classic Chinese Daoism reader) (notice that Roberts does not use the westernized term Taoism) from Chinese to English. Yang (2015) assumes that “major country relationship” is better than "major power relationship” in translating 大国关系 from Chinese to English, arguing that China abides to the principle of peaceful co-existence, non-hegemony and peaceful rise (pp. 101-104). Sun (2013) holds that translation distance exists in the translating process, involving such types as text distance, time distance, identity distance, cultural distance, aesthetic distance, and manipulation distance (pp. 5-12). Munday (2012) advocates a translation quality evaluation model based on Systemic Functionalist Appraisal Theory, supporting the model of "meaning (sense) + emotion (sensibility)” as the core of translation practice and evaluation (p. 16) (see Figure 1):

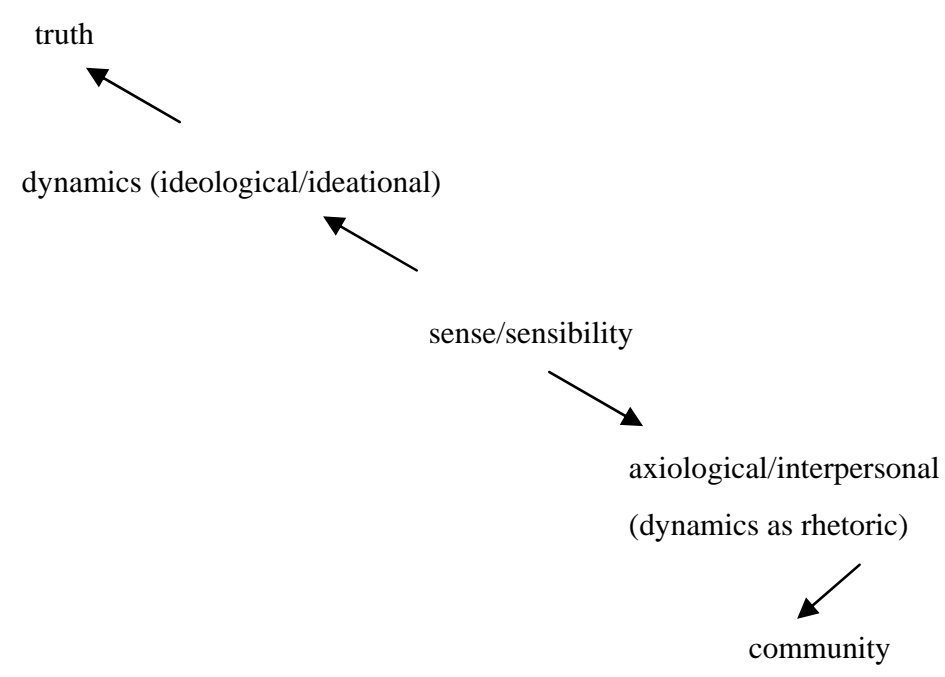

Figure 1. Translation quality evaluation.

\section{Cultural Model in Chinese-to-English Translation}

Baker (2001) borrows the term "game theory" from economics and argues that translation resembles math and economics where there are losers and winners and even zero sum game; likewise, translation contents include definitional (formative) and selective components. The translator is entitled to preserving the original contents, adding some contents, or deleting some contents as needed (p. 91). Baker's theory seems to match Munday's idea concerning the translator's position and inputs. In this paper we argue for a cultural model in Chinese-to-English translation as follows: 


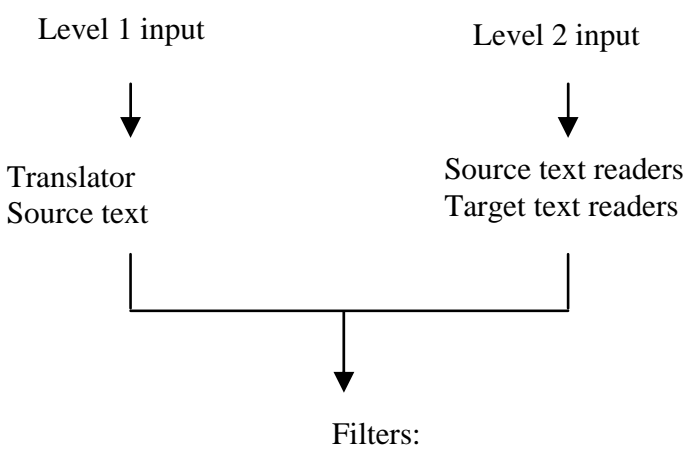

Cultural elements (source language vs. target language cultures)

Source text writer's intention

Translator's intention

Context of situation

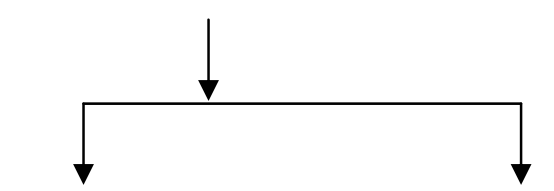

Level 1 output: $\quad$ Level 2 output:

Target text Communication between the translator and the target text readers

Figure 2. Cultural model in Chinese-to-English translation.

From Figure 2 we can see that our cultural model, based on previous research, takes into account participants, cultures, and context in producing a desirable target text and facilitating the communication between the translator and the target text readers. The inputs have to undergo the filtering stage before turning into efficient and effective components in the translation products. In fact, the translation products are not merely the target text, but includes an indispensable part as well—communication between the translator and the target text readers. To achieve the end, the translator has to adopt appropriate techniques as necessary in the translating process.

\section{Translation Practice of Guizhou's Local Culture}

Consider the following example for translation from Chinese to English:

中国土司遗址在第39届联合国教科文组织世界遗产委员会会议(世界遗产大会)上获准列入世界遗产名录,成为 中国第48处世界遗产。世界遗产委员会各成员在当天会议中一致同意将土司遗址列为世界遗产。土司遗址为中国 2015年申报世界文化遗产项目,包括湖南永顺老司城、湖北唐崖土司城和贵州播州海龙屯三处遗址。

(Website document, unauthored, 2017, https://baike.baidu.com/item)

Tusi culture is an important part of Guizhou's local culture in the Ming and Qing Dynasties. International readers may be uninformed of this historic component, hence possessing a cultural gap. In order to bridge the gap and facilitate the communication, the translator should add some historic background concerned, thus adopting the translation technique of adding. The following is an English version of the Chinese publicity: 
Tusi, a title of local chieftain particularly in remote minority areas of ancient China, lasting from the Tang Dynasty (about 7th century AD) to the Qing Dynasty (about the late 19th century), is a way of central feudal government's ruling. The notion behind this way of governance is the governance of aborigines and minorities by their representatives, who were granted certain ranks of officialdom, inherited by their descendants. The present famous relics of Tusi culture include Old Yongshun Tusi Town of Hunan, Tangya Tusi Town of Hubei and Hailongtun Tusi Ruin of Bozhou in Guizhou. The 39th UNESCO World Heritage Committee Conference approved these three Tusi relics as world heritage. Surely, it would motivate more foreign and Chinese tourists to visit these places, imbue the locals with a proud sense of history and heritage, and encourage the Chinese government to protect cultural relics in the era of globalization and economic development for the sake of sustainable development.

It is worth mentioning that our translation supplements such evaluative wordings as surely, and it would motivate. In Martin and White's view (2005), this is a device of dialogic expansion and a mark of participants' appreciation (pp. 202-205). It is also a way of low context manipulation for the target text readers.

Take another example:

社饭

苗、侗、伦佬等少数民族节日食品。贵州少数民族都有“赶社”的习俗。社饭是社节的重要食品。吃社饭的历 史渊源可上溯到唐宋时代。据史载, 农历每年立春的第五个戊日为社日, 是祭祀土地的日子。每年春分季节, 蒿 菜发芽的时候，人们都去打来参在饭中食用，久而久之就成了今天独具特色的“社饭”。“社饭”用的主要原料有糯 米、籼米、腊肉、豆腐干、血豆腐、花生仁、野蒿菜叶、春芽、野葱及大蒜叶等，其余佐料因传承人而异。“社饭” 具有特殊的芬香味, 美味可口, 存放十天半月不会变质。冷却后再复炒, 更加味美, 有补体中气不, 益脾健胃等 特殊功效。社日吃社饭时邀请亲朋好友共餐, 同时还将社当作礼品馈赠亲朋好友, 取来年顺昌, 大家共庆之意。

(Source: Encyclopedia of Traditional Minority Culture of Guizhou Province, p. 69, edited by Guizhou Ethnic Affairs Commission, Guiyang: Guizhou Education Press, January 2013)

This is a text introducing Guizhou's minority people's food. It is advisable to give credit to minority people's culture in the globalization era. Here we adopt the technique of "background introduction + recipe" in order to praise the food and clearly show its ingredients and effects. Plus, a picture showing the food is added so as to present the delicacy in a multimodal way to international readers. The following is the English version recommended:

\section{Communal Rice (She Fan)}

It is a traditional festival food for such minority ethnicities as Miao, Dong and Gelao. In fact, nearly all minority people of Guizhou have the custom of "attending Communal Festival (Gan She)". Communal Rice is an important food at this festival. In terms of history, the custom of eating Communal Rice can be dated back to the Tang and Song Dynasties. Documents record that lunar February 21 after Beginning of Spring is the Communal Festival or a day devoted to religious services to Land God. Every year around Beginning of Spring, tarragon sprouts, and people pick it and mix it with rice. In time Communal Rice, a unique food, has been formed. The following is an account of its ingredients, cooking methods and features:

Ingredients: wild tarragon leaves, sticky rice, non-glutinous rice, preserved pork, dried tofu cake, tofu cake with pig blood, peanut, green shoots, wild scallion, garlic leaves, and other things in relation to individual tastes.

Cooking methods: cold and then heated or stir-fried.

Features: fragrant, lasting for 10 to 15 days without going bad, good for stamina, delicious, and appetizing; suitable as gifts for relatives and friends, symbolizing prosperity and communal celebration. 


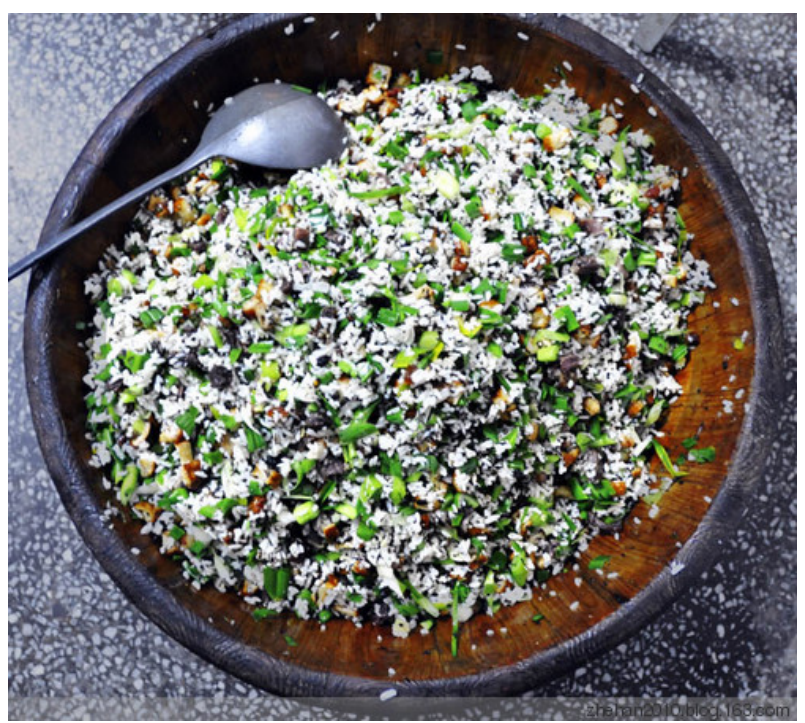

(Source: https://image.baidu.com).

In fact, this is a promotional genre, emphasizing the steps concerned. Hasan (1996) puts forward the concept of GSP (Generic Structure Potential), including the obligatory and optional elements in a text (pp. 50-72). Our translation highlights the generic structure of a promotional text as well as the emotional mediation between the translator and the target text readers. The background information is obligatory, so are the ingredients, while the evaluation of the food is optional, depending on the filter. We choose to preserve the evaluative devices to show our solidarity with the minority people on behalf of the target text readers. Besides, In order to cater to those international tourists who might travel to Guizhou and try local delicacies, Communal Rice is marked in Chinese Pinyin (She Fan) so that a back-translation is available and the food can be rightly identified, so is the activity of “attending Communal Festival” (Gan She). In this way a desirable target text is expected to come into being.

\section{Conclusion}

Cultural turn is a topic worth noticing in translation. In this paper we review the cultural translation theories and practices, propose a cultural model in Chinese-to-English translation, and apply it to the translation of Guizhou's local culture from Chinese to English. Attention to culture in translation is a comprehensive mechanism including inputs, filters and outputs. In order to achieve desirable translation products, the translator has to consider adopting a variety of translating techniques or methods, depending on the context and purpose concerned.

\section{References}

Baker, M. (1992). In other words: A coursebook on translation (pp. 11-260). London: Taylor \& Francis Limited. Baker, M. (2001). Routledge encyclopedia of translation studies (p. 91). London/New York: Routledge. Bell, R. T. (1991). Translation and translating: Theory and practice (p. 9). London/New York: Longman. Cronin, M. (2003). Translation and globalization. London/New York: Routledge.

Guizhou Ethnic Affairs Commission. (2013). Encyclopedia of Traditional Minority Culture of Guizhou Province (p. 69). Guiyang: Guizhou Education Press.

Hasan, R. (1996). Ways of saying: Ways of meaning (pp. 50-72). London: Cassell.

House, J. (2016). Translation as communication across languages and cultures. London/New York: Routledge. 
Katan, D. (1999). Translating culture: An introduction for translators, interpreters and mediators. Manchester: St. Jerome Publishing.

Martin, J. R., \& White, P. (2005). The Language of evaluation: Appraisal in English (pp. 202-205). New York: Palgrave Macmillan. Munday, J. (2012). Evaluation in Translation: Critical points of translator decision-making (p. 16). London: Taylor \& Francis Limited.

Nida, E. A. (2004). Language, culture, and translating (pp. i-ii). Shanghai: Shanghai Foreign Education Press.

Nord, C. (1997). A functional typology of translation. In A. Trosborg (Ed.), Text typology and translation (pp. 49-52). Amsterdam and Philadelphia: John Benjamins.

Roberts, M. (2001). Laozi: Dao De Jing—The Book Of The Way. Berkley, Los Angeles, and London: University of California Press.

Sager, J. C. (1997). Text type and translation. In A, Trosborg (Ed.), Text typology and translation (p. 34). Amsterdam and Philadelphia: John Benjamins.

Slingerland, E. (2003). Confucius Analects. Indianapolis/Cambridge: Indianapolis Hackett Publishing Company, Inc.

Sun, Y. F. (2013). The distance of translation. Chinese Translators Journal, (6), 5-12.

Yang, M. X. (2015). Creative translation of “New Major Country Relationship” and its realistic significance. Chinese Translators Journal, (1), 101-104.

\section{Online source}

https://baike.baidu.com/item/\%E5\%9C\%9F\%E5\%8F\%B8\%E9\%81\%97\%E5\%9D\%80/17989947?fr=aladdin

http://image.baidu.com/search/index?tn=baiduimage\&ct=201326592\&lm=-1\&cl=2\&ie=gbk\&word=\%B6\%E0\%B2\%CA\%B9\%F 3\%D6\%DD\%C9\%E7\%B7\%B9\&fr=ala\&ala=1\&alatpl=adress\&pos=0\&hs=2\&xthttps=000000 